\title{
Control of Annual Weedy Grasses in a Bentgrass Green with Treatment Programs of Tri-calcium Arsenate
}

\author{
Lloyd M. Callahan'and Dennis P. Shepard ${ }^{2}$ \\ Department of Ornamental Horticulture and Landscape Design, University of Tennessee, Knoxville, \\ TN 37901-1071
}

Additional index words. annual bluegrass, large crabgrass, Poa annua var. annua, Digitaria sanguinalis, Agrostis palustris, thatch, arsenic, earthworms, phosphorus

\begin{abstract}
A creeping bentgrass (Agrostis palustris Huds. 'Penncross') green was treated with flowable tri-calcium arsenate (Ca-Ars) in increment levels of 17 or $34 \mathrm{~kg} \cdot \mathrm{ha}^{-1}$ in 12 multiple treatment date programs. Treatments were made over 4 years to determine effectiveness of initial applications and accumulated residues in controlling annual bluegrass (Poa annua var. annua $\mathrm{L}$.) and large crabgrass (Digitaria sanguinalis L. Scop.) and to evaluate the phy-

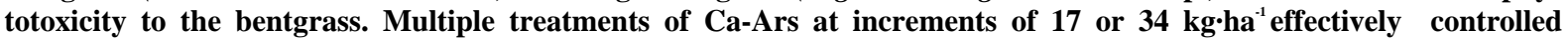

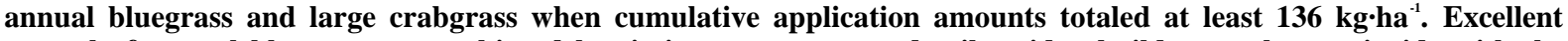
control of annual bluegrass was achieved by timing treatments and soil residue buildup totals to coincide with the major germination and regrowth period of late winter to early spring. Optimum timing included treatments during the fall and spring. This treatment sequence also gave excellent control of crabgrass. Sustained control of both weeds was achieved when continued low level follow-up applications totaled $>136 \mathrm{~kg}^{\circ} \mathrm{ha}^{-1}$. Penncross bentgrass appeared tolerant of Ca-Ars treatments totaling as high as $272 \mathrm{~kg} \cdot \mathrm{ha}^{-1}$. Arsenic apparently influenced thatch accumulation by killing earthworms.
\end{abstract}

Turfgrass managers and researchers have been using preemergence herbicides to control annual bluegrass and crabgrass for several decades. Many chemicals have been effective in controlling crabgrass (Callahan, 1986; Hall et al., 1974; Jagschitz, 1972; Juska, 1961; Murray et al., 1983). However, chemical controls for" annual bluegrass have been only partially successful (Carrow and Rieke, 1977; Daniel, 1955; Freeborg and Daniel, 1972; Kerr, 1969). One of the more successful herbicides for annual bluegrass control has been calcium arsenate (Ca-Ars), but incorrect timing of a single application often resulted in poor success (Carrow and Rieke, 1977; Daniel, 1955; Freeborg and Daniel, 1972; Kerr, 1969). Arsenical have been used as herbicides since the 1920s (Ross and Lembi, 1985) and were in use on $>2000$ golf courses to control annual bluegrass before 1972 (Freeborg and Daniel, 1972).

Although arsenic can be an effective herbicide for the control of annual bluegrass and crabgrass, it also has the potential to be phytotoxic to turfgrasses (Callahan, 1972, 1976; Carrow et al., 1975; Cole and Turgeon, 1978; Ross and Lembi, 1985; Turgeon et al., 1974). The chances for phytotoxicity are great when arsenic is applied as an annual preemergence treatment at a single very high rate. Thus, determining proper rates, timing, and frequency of treatments becomes a very important factor in safety to the turfgrass (Daniel, 1955; Kerr, 1969).

Reports vary on the influence of $\mathrm{P}$ on herbicidal activity of arsenic and the phytotoxicity of arsenic to turfgrasses. According to Ross and Lembi (1985), arsenic, like P, is tightly bound in soil and resists leaching by water. Elemental arsenic does not break down, so there is potential for accumulation of residues in soil if used repeatedly. Woolson et al. (1973) reported the

Received for publication 11 Sept. 1989. Partial support of this research by Mallinckrodt, Inc., now Sierra Chemical Co., is gratefully acknowledged. The cost of publishing this paper was defrayed in part by the payment of page charges. Under postal regulations, this paper therefore must be hereby marked advertisement solely to indicate this fact.

'Professor.

${ }^{2}$ Former Research Associate. amount of $\mathrm{P}$ in the soil solution appeared to govern the uptake of arsenic by corn (Zea mays L.) plants. When solution $\mathrm{P}$ was high, arsenic was apparently less toxic. However, Carrow et al. (1975) found that increased arsenic levels decreased growth of turfgrasses regardless of $\mathrm{P}$ levels in soil. Phosphorus had little or no effect on arsenic toxicity exhibited by turfgrass growth even under very high $\mathrm{P}\left(4 \mathrm{~kg} \mathrm{P} / 100 \mathrm{~m}^{2}\right)$.

Early recommendations advocated that, to increase arsenic uptake for effective annual weed grass control, soil $\mathrm{pH}$ should be maintained between 6.0 and 7.8 and $\mathrm{P}$ should be reduced so it would not compete with arsenic uptake (Kerr, 1969). However, Juska (1961) reported increased phytotoxicity to turfgrasses and $100 \%$ control of annual bluegrass with $\mathrm{Ca}$-Ars at $582 \mathrm{~kg} \cdot \mathrm{ha}^{-1}$ in a high $\mathrm{P}$ and $\mathrm{K}$ loam soil with a $\mathrm{pH}$ of 5.5 . According to Hall et al. (1974), Ca-Ars at $209 \mathrm{~kg} \cdot \mathrm{ha}^{-1}$ significantly reduced turfgrass root numbers and controlled crabgass when applied to a soil high in $\mathrm{P}$, medium in $\mathrm{K}$, and with a $\mathrm{pH}$ of 6.0 .

Arsenic can affect turfgrass quality by influencing thatch accumulation. Turgeon et al. (1974) found thatch to increase in a 'Merion' Kentucky bluegrass (Poa pratensis L.) lawn following 8 years of annual Ca-Ars treatments at $683 \mathrm{~kg} \cdot \mathrm{ha}^{-1}$. They attributed thatch buildup to elimination of earthworms (Lumbricus terrestris Linn. ) since Ca-Ars functions also as an insecticide. In a subsequent study, Turgeon et al. (1975) showed significant thatch increases in a 'Kenblue' Kentucky bluegrass lawn following four annual applications of Ca-Ars at $439 \mathrm{~kg} \cdot \mathrm{ha}^{-1}$. Again, thatch accumulation was associated with a complete lack of earthworms. When the test area was examined for microbial abundance and activity, amount of undecomposed plant material was greatest in arsenic-treated plots in which microbial activity was most severely affected (Cole and Turgeon, 1978). These results suggest that increased residue accumulation was the direct consequence of a reduction in soil microorganisms, earthworms, and insects.

Calcium-arsenate has the characteristics to be an excellent herbicide for selective control of annual bluegrass and crabgrass in turfgrasses generally sensitive to herbicides. This study was 
conducted to determine the effectiveness of coordinated timing and frequency of very low treatment levels of Ca-Ars in gradually removing annual bluegrass and large crabgrass in a 'Penncross' bentgrass green. An important aspect of the study included determining the safety of the various accumulated soil residue levels of $\mathrm{Ca}$-Ars to the bentgrass.

\section{Materials and Methods}

These investigations were conducted on a PURR-WICK green (Daniel, 1970), $14 \times 20 \mathrm{~m}$ in size, newly constructed in 1984 to confine arsenic treatments. The top $20 \mathrm{~cm}$ of the root zone over plastic was off-site mixed and consisted of $94.5 \%$ medium fraction sand, $2.1 \%$ silt, $1.0 \%$ clay, and $2.4 \%$ organic matter (OM) by weight. The bottom $10 \mathrm{~cm}$ of the root zone was $100 \%$ medium fraction sand. A laboratory physical analysis of the root zone mixture showed $34 \%$ noncapillary and $16 \%$ capillary pores. Bulk density was $1.43 \mathrm{~g} \cdot \mathrm{cm}^{-3}$ and infiltration and percolation rate was $21 \mathrm{~cm} \cdot \mathrm{hr}^{-1}$.

Seedbed preparation consisted of thoroughly mixing dolomitic limestone, ammonium nitrate, super phosphate, and sulfate of potash into the top $15 \mathrm{~cm}$ of the root zone. An initial soil test indicated a $\mathrm{pH}$ of $5.2,38 \mathrm{~kg} \mathrm{P} / \mathrm{ha}$, and $235 \mathrm{~kg} \mathrm{~K} / \mathrm{ha}$. A soil test at the conclusion of the study during Fall 1988 showed a $\mathrm{pH}$ of $6.4, \mathrm{P}$ at $19 \mathrm{~kg} \cdot \mathrm{ha}^{-1}$, and $\mathrm{K}$ at $46 \mathrm{~kg} \cdot \mathrm{ha}^{-1}$. The green was fumigated with methyl bromide at $974 \mathrm{~kg} \cdot \mathrm{ha}^{-1}$ in August and seeded with thiadiazole-treated 'Penncross' bentgrass seed 7 Sept. 1984. Bentgrass annual maintenance fertilization totaled 294N-0P-164K kg.ha ${ }^{-1}$. Nitrogen applications were divided equally between March, April, May, September, October, and November. Potash applications were divided equally between March, April, September, and October. The green was mowed five times per week at a $4.5-\mathrm{mm}$ cutting height with clippings caught and removed. Irrigation was from one to three times per week, as needed, to prevent wilting, supplying $25 \mathrm{~mm}$ of water each time. Fungicides were applied as needed to control parasitic diseases. The test area was lightly dethatched with a vertical. mower and lightly topdressed with medium fraction sand in April and October of each year for thatch control. No core aeration was performed. .

Plot sizes were $1.2 \times 4.2 \mathrm{~m}$ arranged in a randomized complete-block design with three replications per treatment and four untreated plots per replication. Harvested and cleaned seed of annual bluegrass and large crabgrass were seeded with a gravity spreader into respective 1.2-m-wide strips across each plot. Just before weed seeding, strips were vertically mowed with a dethatching machine and then vacuumed. Annual bluegrass was seeded at $244 \mathrm{~kg} \cdot \mathrm{ha}^{-1} \approx 1 \mathrm{Feb}$. and again $15 \mathrm{Aug}$. and large crabgrass was seeded at $488 \mathrm{~kg} \cdot \mathrm{ha}^{-1} \approx 1$ Feb. Very high seedings of $488 \mathrm{~kg} \cdot \mathrm{ha}^{-1}$ were used for crabgrass for initial and annual reseedings as compared to annual bluegrass seedings of $244 \mathrm{~kg} \cdot \mathrm{ha}^{-1}$. Previous research using $244 \mathrm{~kg} \cdot \mathrm{ha}^{-1}$ of crabgrass in very high porosity greens indicated a need to increase the seeding amount considerably to assure a higher percent of annual germination in order to achieve more accurate weed control results (Callahan, 1986). The high seeding rates were necessary to sustain the sequential type of results required in this study.

Seeding of weed grasses began 1 Feb. 1985 and continued annually to 1 Feb. 1988. Because of the competitive nature of bentgrass and the need to maintain continuous infestations of the target weedy grasses, the weed grass strips received no maintenance fertilizations. Annual reseeding of a fresh supply of annual bluegrass and crabgrass posed a severe test on the effectiveness of the $\mathrm{Ca}$-Ars treatment programs unlike normal infestations under natural golf green conditions. However, reseeding was necessary to test the effectiveness of the widely spaced multiple treatment date programs and the effectiveness of soil residues of arsenic in controlling the weeds.

All arsenic treatments were tri-calcium arsenate, $26 \%$ flowable, and were applied with a gauged, pressurized, hand-held sprayer delivering 406 liter-ha $^{-1}$ We used Ca-Ars at either 17 or $34 \mathrm{~kg} \cdot \mathrm{ha}^{-1}$, depending upon which treatment program was being applied. The entire green was irrigated with $25 \mathrm{~mm}$ of water immediately following the last Ca-Ars application for each date. All Ca-Ars treatments were applied on about the 15 th of each month in each of the respective programs. Calcium-arsenate treatment programs by year are shown in Table 1.

A single Ca-Ars treatment (programs 11 and 12) was made 1 Ott. 1984 , on bentgrass seedlings when they were $\approx 2$ weeks old. Intended follow-up treatments were omitted due to extensive kill of the seedlings and the need for reseeding. The first series of treatment programs began 15 Mar. 1985 and ended 15 Nov. 1986. After completion of the first series of programs and data evaluation, a follow-up series of programs was started 15 Mar. 1987 and ended 15 May 1988. Treatment programs consisted of applications of Ca-Ars at 17 and/or $34 \mathrm{~kg} \cdot \mathrm{ha}^{-1}$ applied in variable combinations in March, April, May, September, October, and November.

Visual assessments of bentgrass stand density in each plot were based on percent sod cover and reflect the portion of the plot not seeded to weed grasses. Foliage coloration of bentgrass was recorded weekly and included leaf blade reaction to arsenic as yellowing or browning, which was used to aid interpretation of results. Annual bluegrass and crabgrass control was assessed by visual density of each in their respective plots and converted to percent control relative to percentages of these weeds in untreated control plots. Calcium-arsenate treatments were considered effective when they resulted in weedy grass control $\geq 90 \%$ Data were collected weekly throughout the year and subjected to analysis of variance consistent with a randomized completeblock design and completed via PROC GLM in SAS (Sas Institute, Cary, N.C.). Means were partitioned using least significant differences with alpha-risk set at 0.05.

Thatch measurements were taken annually in the fall by measuring the thickness of the thatch layer in four randomly collected profile plugs $1.6 \times 8 \times 3 \mathrm{~cm}$ (width/length/depth) from each plot. Earthworm activity following water saturations of plots was observed during Fall 1987 and Spring and Summer 1988. In Oct. 1988, four 10-cm-dia. $\times 18$-cm-deep soil cores were examined in all plots for earthworms.

\section{Results and Discussion}

Annual bluegrass control. Calcium-arsenate totals and treatment concentrations during 1985 were insufficient to produce desired annual bluegrass control of $\geq 90 \%$

By the end of Spring 1986, program 8 was giving $100 \%$ control with an accumulated Ca-Ars total of $170 \mathrm{~kg} \cdot \mathrm{ha}^{-1}(\mathrm{Ta}-$ bles 1 and 2). However, no follow-up treatments were made during Fall 1986 and program 8 dropped to $73 \%$ control. Program 7 gave $93 \%$ control by June 1986 with an accumulated Ca-Ars total of $136 \mathrm{~kg} \cdot \mathrm{ha}^{-1}$. However, with no fall follow-up treatments, program 7 dropped to $61 \%$ control. The only other effective program in 1986 was program 15, which gave 90\% control with an accumulated Ca-Ars total of $136 \mathrm{~kg} \cdot \mathrm{ha}^{-1}$. Results for 1986 indicate that when Ca-Ars accumulated totals were inadequate due to lack of follow-up treatments, and allow- 
Table 1. Tri-calcium arsenate treatment programs and sequences in a 'Penncross' bentgrass green from 1984 to 1988.

\begin{tabular}{|c|c|c|}
\hline \multirow{2}{*}{$\begin{array}{l}\text { Program } \\
\text { no. }{ }^{2}\end{array}$} & \multicolumn{2}{|c|}{ Applications of Ca-Ars $\left(\mathrm{kg} \cdot \mathrm{ha}^{-1}\right)$ in years indicated } \\
\hline & 1984,1985 , and 1986 & 1987 and 1988 \\
\hline 1 & 34 kg Sept. +17 kg Oct. \& Nov. 1985 & \\
\hline 2 & 34 kg Sept., Oct. \& Nov. 1985 & 17 kg Sept., Oct. \& Nov. 1987 \\
\hline 3 & $34 \mathrm{~kg}$ Mar. + $17 \mathrm{~kg}$ Apr. \& May 1985 & \\
\hline 4 & 34 kg Mar., Apr., \& May 1985 & 17 kg Mar., Apr., \& May 1987 \\
\hline 6 & $\begin{array}{l}34 \mathrm{~kg} \text { Mar. }+17 \mathrm{~kg} \mathrm{Apr}, \text { May }+ \\
34 \mathrm{~kg} \text { Sept. }+17 \mathrm{~kg} \text { Oct. \& Nov. } 1985\end{array}$ & $\begin{array}{l}17 \text { kg Mar., Apr., \& May + } \\
17 \text { kg Sept., Oct., \& Nov. } 1987\end{array}$ \\
\hline 7 & $\begin{array}{r}34 \mathrm{~kg} \mathrm{Sept.}+17 \mathrm{~kg} \text { Oct. \& Nov. } 1985+ \\
34 \mathrm{~kg} \text { Mar. }+17 \mathrm{~kg} \text { Apr. \& May } 1986\end{array}$ & \\
\hline 8 & $\begin{array}{l}34 \mathrm{~kg} \text { Sept. }+17 \mathrm{~kg} \text { Oct. \& Nov. } 1985+ \\
34 \mathrm{~kg} \text { Mar., Apr., \& May } 1986\end{array}$ & $\begin{array}{c}17 \text { kg Sept., Oct., \& Nov. } 1987+ \\
17 \text { kg Mar., Apr., \& May } 1988\end{array}$ \\
\hline 11 & 34 kg Oct. 1984 & $\begin{array}{l}34 \mathrm{~kg} \text { Mar. }+17 \mathrm{~kg} \text { Apr. \& May }+ \\
34 \mathrm{~kg} \text { Sept. }+17 \mathrm{~kg} \text { Oct. \& Nov. } 1987\end{array}$ \\
\hline 12 & $34 \mathrm{~kg}$ Oct. 1984 & $\begin{array}{l}34 \text { kg Mar., Apr., \& May + } \\
34 \text { kg Sept., Oct., \& Nov. } 1987\end{array}$ \\
\hline 13 & $\begin{array}{l}17 \mathrm{~kg} \mathrm{Sept.} \mathrm{\&} \mathrm{Nov.} 1985+ \\
17 \mathrm{~kg} \text { Mar. \& Sept. } 1986\end{array}$ & $\begin{array}{l}17 \text { kg Mar. \& Apr. + } \\
17 \text { kg Sept. \& Oct. } 1987\end{array}$ \\
\hline 14 & $\begin{array}{l}17 \mathrm{~kg} \text { Sept., Oct. \& Nov. } 1985+ \\
17 \mathrm{~kg} \text { Mar., Apr., \& Sept. } 1986\end{array}$ & $\begin{array}{l}17 \text { kg Mar. \& Apr. + } \\
17 \text { kg Sept., Oct., \& Nov. } 1987\end{array}$ \\
\hline 15 & $\begin{array}{l}17 \text { kg Sept., Oct., \& Nov. } 1985+ \\
17 \mathrm{~kg} \text { Mar. \& Apr. } 1986+ \\
17 \mathrm{~kg} \text { Sept., Oct., \& Nov. } 1986\end{array}$ & $\begin{array}{l}17 \text { kg Mar., Apr., \& May + } \\
17 \text { kg Sept., Oct., \& Nov. } 1987\end{array}$ \\
\hline
\end{tabular}

${ }^{2}$ Programs 5, 9, 10, and 16 were untreated controls.

Table 2. Annual bluegrass control with treatment programs of tricalcium arsenate compared to untreated controls in a 'Penncross' bentgrass green from 1985 to $1988 .{ }^{2}$

\begin{tabular}{|c|c|c|c|c|c|c|c|c|c|c|}
\hline \multirow{4}{*}{$\begin{array}{l} \\
\text { Program } \\
\text { no.y }\end{array}$} & \multirow{3}{*}{\multicolumn{4}{|c|}{$\begin{array}{l}\text { Tri-calcium arsenate } \\
\text { totals by year }\left(\mathrm{kg} \cdot \mathrm{ha}^{-1}\right)\end{array}$}} & \multicolumn{6}{|c|}{$\begin{array}{c}\text { Annual bluegrass control } \\
\text { following seasonal treatments }(\%)^{\mathrm{x}}\end{array}$} \\
\hline & & & & & \multirow{3}{*}{$\begin{array}{c}1985 \\
22 \\
\text { Nov. }\end{array}$} & \multicolumn{2}{|c|}{1986} & \multicolumn{2}{|c|}{1987} & \multirow{3}{*}{$\frac{1988}{3}$} \\
\hline & & & & & & 5 & 21 & 5 & 24 & \\
\hline & 19841985 & 1986 & 1987 & 1988 & & June & Nov. & June & Nov. & \\
\hline 1 & 68 & & & & 69 & 46 & 6 & 0 & 0 & 0 \\
\hline 2 & 102 & & 51 & & 79 & 68 & 12 & 0 & 58 & 23 \\
\hline 3 & 68 & & & & 6 & 0 & 0 & 0 & 0 & 0 \\
\hline 4 & 102 & & 51 & & 29 & 33 & 6 & 61 & 31 & 14 \\
\hline 6. & 136 & & 102 & & 71 & 73 & 21 & 100 & 100 & 100 \\
\hline 7 & 68 & 68 & & & 70 & 93 & 61 & 53 & 21 & 4 \\
\hline 8 & 68 & 102 & 51 & 51 & 64 & 100 & 73 & 61 & 100 & 100 \\
\hline 11 & 34 & & 136 & & 0 & 0 & 0 & 71 & 97 & 100 \\
\hline 12 & 34 & & 204 & & 0 & 0 & 0 & 95 & 100 & 100 \\
\hline 13 & 34 & 34 & 68 & & 26 & 60 & 30 & 77 & 85 & 97 \\
\hline 14 & 51 & 51 & 85 & & 39 & 81 & 70 & 100 & 100 & 100 \\
\hline 15 & 51 & 85 & 102 & & 30 & 81 & 90 & 100 & 100 & 100 \\
\hline LSD $(0.05)$ & & & & & 7.9 & 3.9 & 4.9 & 2.9 & 7.2 & 3.6 \\
\hline
\end{tabular}

${ }^{2}$ Annual bluegrass was seeded annually in early February and late August from 1985 to 1988.

'Plots 5, 9, 10, and 16 were untreated controls.

${ }^{x}$ Table 1 gives expanded treatment dates and rates within years.

"Data are means of three replications and were partitioned using LSD with alpha-risk set at 0.05 .

ing several months for dissipation, control of annual bluegrass was gradually or drastically reduced.

With the combination of new Ca-Ars applications and soil residue accumulations during 1987, effectiveness of the treatment programs improved substantially (Tables 1 and 2). Annual bluegrass control was $100 \%$ by 5 June 1987 with programs 6 , 14 , and 15 , and $95 \%$ with program 12 . Calcium-arsenate totals by 5 June were $187,136,187$, and $136 \mathrm{~kg} \cdot \mathrm{ha}^{-1}$, respectively, for programs $6,14,15$, and 12. By 24 Nov. 1987, annual bluegrass control was $100 \%$ with programs $6,8,12,14$, and
15 , and $97 \%$ with program 11 . Totals of Ca-Ars by 24 Nov. were $238,221,238,187,238$, and $170 \mathrm{~kg} \cdot \mathrm{ha}^{-1}$ respectively, for programs $6,8,12,14,15$, and 11 . With the substantial increases in Ca-Ars totals during Fall 1987, selected programs considerably increased in effectiveness of annual bluegrass control.

Program 8 treatments were the only applications made during 1988 and were applied only during the spring (Tables 1 and 2). Annual bluegrass control with other programs was the result of soil residue "carryover from treatments made during previous 
years. Annual bluegrass control was $100 \%$ during 1988 with programs $6,8,11,12,14$, and 15, and 97\% with program 13 . By 3 June 1988, Ca-Ars totals for program 8 had increased to $272 \mathrm{~kg} \cdot \mathrm{ha}^{-1}$. Calcium-arsenate for programs 6, 11, 12, 14, and 15 remained at the levels they had reached in Nov. 1987. Program 13 gave only $85 \%$ control by 24 Nov. 1987 with a CaArs total of $136 \mathrm{~kg} \cdot \mathrm{ha}^{-1}$. However, control effectiveness of program 13 reached $97 \%$ by Spring 1988 with no additional CaArs treatments due to sufficient soil residues being present during this late-winter germination and regrowth period for annual bluegrass.

In summary, the low treatment levels of either 17 or $34 \mathrm{~kg} \cdot \mathrm{ha}^{-1}$ proved effective in gradually removing annual bluegrass from the bentgrass when treatment totals reached at least $136 \mathrm{~kg} \cdot \mathrm{ha}^{-1}$. Annual bluegrass control was sustained with continued followup treatments totaling $>136 \mathrm{~kg} \cdot \mathrm{ha}^{-1}$. Control appeared to be most effective when treatments were applied during fall (September, October, and November) followed by spring treatments (March, April, and May). The most effective programs, which reached $100 \%$ control of annual bluegrass, were $6,8,11,12$, 13,14 , and 15. Programs giving sustained control for the longest period were $6,8,14$, and 15 .

Large crabgrass control. In Spring 1985, programs 3, 4, and 6 gave $100 \%$ control of crabgrass with Ca-Ars totals of 68 or $102 \mathrm{~kg} \cdot \mathrm{ha}^{-1}$ applied in Mar., Apr., and May 1985 (Tables 1 and 3). By Spring 1986, crabgrass control was $96 \%$ to $100 \%$ with programs $2,4,7,8$, and 15 . Calcium-arsenate totals increased to $102,102,136,170$, and $85 \mathrm{~kg} \cdot \mathrm{ha}^{-1}$, respectively, for programs $2,4,7,8$, and 15 .

On 12 June 1987, crabgrass control ranged from $90 \%$ to $99 \%$ for programs $6,11,12,13,14$, and 15 (Tables 1 and 3). Calcium-arsenate soil residue carryover and renewal treatments should have been sufficient to give 100\% control. By 12 June 1987, the test area had already received three heavy crabgrass seedings. Apparently, dissipation and tie-up of arsenic in soil, combined with the heavy supply of crabgrass seed, diminished the effectiveness of Ca-Ars in controlling crabgrass.

By 22 June 1988, high soil arsenic residues, combined with current treatments, were sufficient to overcome the heavy crabgrass seed reserve, and $90 \%$ to $100 \%$ control was achieved with programs 8,12 , and 15 (Tables 1 and 3). Calcium-arsenate totals by this time had reached 272, 238, and $238 \mathrm{~kg} \cdot \mathrm{ha}^{-1}$, respectively, for programs 8,12 , and 15 . By 14 Oct. 1988 , only program 8 was able to sustain effective control of crabgrass with the ultra-high soil residues of $272 \mathrm{~kg} \cdot \mathrm{ha}^{-1}$.

Arsenic effects on bentgrass. A single Ca-Ars treatment of $34 \mathrm{~kg} \cdot \mathrm{ha}{ }^{-1}$ was made 1 Oct. 1984 in two plots (programs 11 and 12) on 2-week-old 'Penncross' bentgrass seedlings (Table 1). The intention was to follow-up with two separate multiple treatment programs on the seedlings. However, the $34 \mathrm{~kg} \cdot \mathrm{ha}^{-1}$ treatments killed $98 \%$ and $95 \%$ of the bentgrass, respectively, in plots 11 and 12 (Tables 1 and 4), necessitating reseeding. Four reseedings were made in late Oct. and mid-Nov. 1984 and in mid-Feb. and mid-Mar. 1985. Seedling stand density on 12 June 1985" reached $95 \%$ and 99\%, respectively, in plots 11 and 12 (Table 4).

'Penncross' bentgrass in the test area had reached an average density of $89 \%$, omitting plots 11 and 12, by 8 Oct. 1984 (Table 4). By 12 June 1985, bentgrass average density reached 99\%, omitting plots 11 and 12. Formal Ca-Ars treatment programs began 15 Mar. 1985 (Table 1). A few hours after almost every Ca-Ars application, throughout the period of this study, bentgrass foliage exhibited discoloration ranging from a faint to a prominent yellowing that lasted from 2 to 5 weeks. The only time during the entire test period that bentgrass showed any foliage browning was within a 2 -week period following the 15 Mar. and 15 Apr. 1985 programs 3, 4, and 6 treatments (Tables 1 and 4). Bentgrass was in a juvenile stage of growth during this period and apparently was mildly vulnerable to arsenic phytotoxicity. Bentgrass stand densities during 1985 that were significantly lower than that of the controls resulted with programs 1 and 11 with densities of $92 \%$ and $95 \%$, respectively (Table 4).

Bentgrass stand densities during 1986 that were significantly lower than controls occurred with programs 1 and 8, with densities from $94 \%$ to $96 \%$ (Tables 1 and 4 ).

Table 3. Large crabgrass control with treatment programs of tricalcium arsenate compared to untreated controls in a bentgrass green from 1985 to $1988 .^{2}$

\begin{tabular}{|c|c|c|c|c|c|c|c|c|c|c|c|}
\hline \multirow{4}{*}{$\begin{array}{l}\text { Program } \\
\text { no. } .^{y}\end{array}$} & & & & & \multicolumn{7}{|c|}{$\begin{array}{l}\text { Crabgrass control } \\
\text { following seasonal treatments }(\%)\end{array}$} \\
\hline & \multirow{2}{*}{\multicolumn{4}{|c|}{$\begin{array}{l}\text { Tri-calcium arsenate } \\
\text { totals by year }\left(\mathrm{kg} \cdot \mathrm{ha}^{-1}\right)\end{array}$}} & \multirow{3}{*}{ 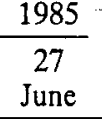 } & \multicolumn{2}{|c|}{1986} & \multicolumn{2}{|c|}{1987} & \multicolumn{2}{|c|}{1988} \\
\hline & & & & & & \multirow{2}{*}{$\begin{array}{c}19 \\
\text { June }\end{array}$} & \multirow{2}{*}{$\begin{array}{c}17 \\
\text { Oct. }\end{array}$} & \multirow{2}{*}{$\begin{array}{c}12 \\
\text { June }\end{array}$} & \multirow{2}{*}{$\begin{array}{c}29 \\
\text { Sept. }\end{array}$} & \multirow{2}{*}{$\begin{array}{c}22 \\
\text { June }\end{array}$} & \multirow{2}{*}{$\begin{array}{c}14 \\
\text { Oct. }\end{array}$} \\
\hline & 19841985 & 1986 & 1987 & 1988 & & & & & & & \\
\hline 1 & 68 & & & & 0 & 49 & 23 & 0 & 0 & 0 & 0 \\
\hline 2 & 102 & & 51 & & 0 & 98 & 79 & 11 & 20 & 18 & 2 \\
\hline 3 & 68 & & & & 100 & 62 & 62 & 0 & 0 & 0 & 0 \\
\hline 4 & 102 & & 51 & & 100 & 96 & 81 & 89 & 48 & 42 & 20 \\
\hline 6 & 136 & & 102 & & 100 & 89 & 77 & 95 & 94 & 71 & 65 \\
\hline 7 & 68 & 68 & & & 0 & 100 & 100 & 77 & 35 & 24 & 9 \\
\hline 8 & 68 & 102 & 51 & 51 & 0 & 100 & 100 & 84 & 89 & 100 & 100 \\
\hline 11 & 34 & & 136 & & 6 & 0 & 0 & 91 & 95 & 82 & 75 \\
\hline 12 & 34 & & 204 & & 6 & 0 & 0 & 96 & 100 & 90 & 84 \\
\hline 13 & 34 & 34 & 68 & & 0 & 38 & 70 & 90 & 95 & 57 & 43 \\
\hline 14 & 51 & 51 & 85 & & 0 & 85 & 82 & 93 & 97 & 64 & 56 \\
\hline 15 & 51 & 85 & 102 & & 0 & 100 & 100 & 99 & 100 & 93 & 83 \\
\hline $\operatorname{LSD}(0.05)^{\mathbf{w}}$ & & & & & 4.1 & 7.2 & 4.6 & 10.8 & 10.5 & 11.0 & 9.9 \\
\hline
\end{tabular}

${ }^{2}$ Large crabgrass was seeded annually in early February from 1985 to 1988.

${ }^{y}$ Plots $5,9,10$, and 16 were untreated controls.

${ }^{x}$ Table 1 gives expanded treatment dates and rates within years.

"Data are means of three replications and were partitioned using LSD with alpha-risk set at 0.05 . 
Table 4. Stand density of a 'Penncross' bentgrass green following treatment programs of tri-calcium arsenate from 1985 to 1988 and compared to untreated controls.

\begin{tabular}{|c|c|c|c|c|c|c|}
\hline \multirow[b]{3}{*}{$\begin{array}{l}\text { Program } \\
\text { Ilo. }\end{array}$} & \multirow{3}{*}{$\begin{array}{c}\text { Ca-Ars } \\
\text { totals } \\
\text { 1984-88 } \\
\left(\mathrm{kg} \cdot \mathrm{ha}^{-1}\right)\end{array}$} & \multicolumn{5}{|c|}{$\begin{array}{c}\text { Bentgrass stand density } \\
\text { following seasonal treatments }(\%)^{y}\end{array}$} \\
\hline & & \multirow{2}{*}{$\frac{1984}{8}$} & \multicolumn{2}{|c|}{1985} & \multicolumn{2}{|c|}{1986} \\
\hline & & & $\begin{array}{c}12 \\
\text { June }\end{array}$ & $\begin{array}{l}20 \\
\text { Nov. }\end{array}$ & $\begin{array}{c}12 \\
\text { June }\end{array}$ & $\begin{array}{l}26 \\
\text { Nov. }\end{array}$ \\
\hline 1 & 68 & 88 & 100 & 92 & 94 & 96 \\
\hline 2 & 153 & 91 & 100 & 98 & 98 & 97 \\
\hline 3 & 68 & 91 & 96 & 98 & 96 & 99 \\
\hline 4 & 153 & 91 & 96 & 100 & 98 & 99 \\
\hline 6 & 238 & 87 & 99 & 100 & 97 & 99 \\
\hline 7 & 136 & 90 & 100 & 97 & 97 & 99 \\
\hline 8 & 272 & 89 & 100 & 97 & 97 & 96 \\
\hline 11 & 170 & 2 & 95 & 100 & 97 & 98 \\
\hline 12 & 238 & 5 & 99 & 100 & 97 & 97 \\
\hline 13 & 136 & 93 & 100 & 98 & 96 & 98 \\
\hline 14 & 187 & 89 & 100 & 99 & 96 & 98 \\
\hline 15 & 238 & 87 & 100 & 97 & 96 & 97 \\
\hline \multicolumn{2}{|l|}{ Control } & 88 & 99 & 99 & 97 & 99 \\
\hline \multicolumn{2}{|c|}{$\operatorname{LSD}(0.05)^{\mathrm{w}}$} & 5.6 & 4.3 & 3.4 & 2.3 & 2.7 \\
\hline
\end{tabular}

${ }^{2}$ Bentgrass was seeded 7 Sept. 1984 and germinated 14 Sept. 1984.

'Bentgrass stand density percentages reflect the portion of the plot not seeded to weeds.

${ }^{x}$ Check or untreated plot reflects four controls per replication (plots 5, 9, 10, and 16). None of the differences were significant in 1987 or 1988

"Data are means of three replications and were partitioned using LSD with alpha-risk set at 0.05 .

Bentgrass stand densities for all Ca-Ars programs during 1987 and 1988 ranged from $93 \%$ to $99 \%$, with none of the differences being significant. Calcium-arsenate totals for the leading weed control programs by 1987 and 1988 had reached levels of 238 $\mathrm{kg} \cdot \mathrm{ha}{ }^{-1}$ for programs 6,12 , and 15 , and $272 \mathrm{~kg} \cdot \mathrm{ha}{ }^{-1}$ for program 8. In general, mature 'Penncross' bentgrass maintained under golf-green conditions appeared tolerant of Ca-Ars when treatments were applied at increments of 17 or $34 \mathrm{~kg} \cdot \mathrm{ha}^{-1}$ in multi-date treatment programs.

Arsenic influence on thatch accumulation. Significant levels of thatch accumulation began developing during 1986 with programs 6 through 15 (Table 5). Significant thatch increases above untreated controls during 1987 occurred with programs $2,4,5$, $8,11,12,13,14$, and 15 with thatch thicknesses from 5.9 to $7.2 \mathrm{~mm}$. Program 8, with a thick thatch buildup $(7.2 \mathrm{~mm})$, contributed to mild mower scalping in all plot replications during Aug. 1987. By Oct. 1988 all Ca-Ars program treatments were completed. The highest thatch buildup $(8.7$ and $8.0 \mathrm{~mm})$ occurred with programs 8 and 12, respectively (Table 5). Program 8 totaled $272 \mathrm{~kg} \mathrm{Ca}-\mathrm{Ars} / \mathrm{ha}^{-1}$ and program 12 totaled 238 $\mathrm{kg} \cdot \mathrm{ha} \mathrm{a}^{-1 .}$

No earthworms were found in any of the Ca-Ars program treatment plots (Table 5). Control plots contained $54 / \mathrm{m}^{2}$. As indicated by Turgeon et al. (1974), Ca-Ars can function as an insecticide and is toxic to earthworms. Based on the buildup of thatch and absence of earthworm activity in Ca-Ars program plots, arsenic clearly influences thatch accumulation.

Phosphorus and $\mathrm{pH}$ influence on arsenic. An initial soil test for $\mathrm{P}$ showed $38 \mathrm{~kg} \cdot \mathrm{ha}^{-1}$, which was high. Following 5 years of maintenance fertilization omitting $\mathrm{P}$ and 4 years of Ca-Ars treatments, a soil test in Fall 1988 showed $19 \mathrm{~kg}$ P/ha, which was low. Due to the very high porosity of the green and lack of $\mathrm{P}$ fertilization, the considerable decrease in soil $\mathrm{P}$ was ex-
Table 5. Thatch thickness in a 'Penncross' bentgrass green following treatment programs of tri-calcium arsenate from 1985 to $1988 .{ }^{2}$

\begin{tabular}{|c|c|c|c|c|c|}
\hline \multirow{2}{*}{$\begin{array}{l}\text { Program } \\
\text { no. }\end{array}$} & \multirow{2}{*}{$\begin{array}{c}\text { Ca-Ars } \\
\text { totals } \\
1984-88 \\
\left(\mathrm{~kg} \cdot \mathrm{ha}^{-1}\right)\end{array}$} & \multicolumn{4}{|c|}{$\begin{array}{l}\text { Mean thatch measurements } \\
\text { in October of each year }(\mathrm{mm})\end{array}$} \\
\hline & & 1985 & 1986 & 1987 & 1988 \\
\hline 1 & 68 & 10.7 & 4.5 & 5.1 & 5.7 \\
\hline 2 & 153 & 10.7 & 5.0 & 6.1 & 6.0 \\
\hline 3 & 68 & 11.0 & 4.4 & 5.3 & 5.7 \\
\hline 4 & 153 & 10.7 & 5.1 & 6.0 & 5.7 \\
\hline 6 & 238 & 10.3 & 6.3 & 6.1 & 6.0 \\
\hline 7 & 136 & 11.0 & 5.3 & 5.3 & 5.7 \\
\hline 8 & 272 & 10.0 & 6.8 & 7.2 & 8.7 \\
\hline 11 & 170 & 10.7 & 5.3 & 6.7 & 5.3 \\
\hline 12 & 238 & 10.3 & 5.5 & 6.7 & 8.0 \\
\hline 13 & 136 & 10.0 & 5.6 & 5.9 & 7.3 \\
\hline 14 & 187 & 10.3 & 5.3 & 6.3 & 6.0 \\
\hline 15 & 238 & 10.3 & 6.3 & 6.8 & 7.0 \\
\hline Controly & & 10.7 & 4.5 & 5.0 & 4.7 \\
\hline $\operatorname{LSD}(0.05)^{x}$ & & NS & 0.68 & 0.63 & 0.94 \\
\hline
\end{tabular}

${ }^{2}$ The green was vertally mowed and sand topdressed September and October of each year beginning just after thatch measurements were made.

${ }^{y}$ Check or untreated plot reflects four controls per replication (plots 5, 9,10 , and 16).

${ }^{x}$ Data are means of three replications and were partitioned using LSD with alpha-risk set at 0.05 .

petted. Judging by the responses of annual bluegrass, crabgrass, and bentgrass in our study (Tables 2, 3, and 4), the initial high soil P level did not diminish the effect of arsenic toxicity, just as was shown by Carrow et al. (1975). Other researchers used very high single arsenic levels, ranging from 209 to $683 \mathrm{~kg} \cdot \mathrm{ha}^{-1}$ (Hall et al., 1974; Juska, 1961; Turgeon et al., 1974, 1975). In this study, very low increment levels of 17 or $34 \mathrm{~kg} \cdot \mathrm{ha}^{-1}$ were used with gradual accumulations over 4 years totaling a maximum of $272 \mathrm{~kg} \cdot \mathrm{ha}^{-1}$.

The initial soil $\mathrm{pH}$ in this study was 5.2 but elevated to 6.4 by the end of the study. There were no clear indications that pH had any influence on arsenic toxicity, as suggested by Kerr (1969), since 100\% control of annual bluegrass and crabgrass occurred during the beginning and end of this study (Tables 2 and 3).

\section{Literature Cited}

Callahan, L.M. 1972, Phytotoxicity of herbicides to a Penncross bentgrass green. Weed Sci. 20:387-391.

Callahan, L.M. 1976. Phytotoxicity of herbicides to a Tifgreen bermudagrass green. Weed Sci. 24:92-98.

Callahan, L.M. 1986. Crabgrass and goosegrass control in a bentgrass green in the transition zone. Agron. J. 78:625-628.

Carrow, R.N. and P.E. Rieke. 1977. Effect of Tricalcium Arsenate formulations on control of annual bluegrass (Pea аппиа L.). Weed Sci. 25:364-367.

Carrow, R. N., P.E. Rieke, and B.G. Ellis. 1975. Growth of turfgrasses as affected by soil phosphorus and arsenic. Soil Sci. Soc. Amer. Proc. 39:1121-1124.

Cole, M.A. and A.J. Turgeon. 1978. Microbial activity in soil and litter underlying Bandane and Calcium Arsenate treated turfgrass. Soil Biol. Biochem. 10:181-186.

Daniel, W.H. 1955. Роа аппиа control with arsenic materials. Golf Course Rpt. 23:5-8.

Daniel, W.H. 1970. PURR-WICK rootzone system for turf. Midwest Turf News \& Res. Lflt. 40. Purdue Univ., W. Lafayette, Ind.

Freeborg, R.P. and W.H. Daniel. 1972. Annual bluegrass control with 
arsenicals—field and laboratory correlations. Proc. N. Central Weed Control Conf. 27:62.

Hall, J. R., E.E. Deal, and A.J. Powell. 1974. Seven years of smooth crabgrass control in turfgrass with registered and experimental herbicides. Proc. Northeastern Weed Sci. Sot. 28:399-405.

Jagschitz, J.A. 1972. Preemergence crabgrass and goosegrass control in turfgrass with herbicides. Proc. Northeastern Weed Sci. Soc. 26:205-210.

Juska, F.V. 1961. Preemergence herbicides for crabgrass control and their effects on germination of turfgrass species. Weeds 9: 137-144.

Kerr, C.F. 1969. Program for gradual removal of Poа апnиа. The Golf Superintendent. 37:28-29.

Murray, J. J., D. L. Klingman, R. G. Nash, and E.A. Woolson. 1983.
Eight years of herbicide and nitrogen fertilizer treatments on Kentucky bluegrass (Poa pratensis L.) turf. Weed Sci. 31:825-831.

Ross, M.A. and C.A. Lembi. 1985. Applied weed science. Burgess Publishing, Minneapolis, Minn. p. 80, 168-169.

Turgeon, A. J., J.B. Beard, D.P. Martin, and W.F. Meggitt. 1974. Effects of successive applications of preemergence herbicides on turf. Weed Sci. 22:349-352.

Turgeon, A. J., R.P. Freeborg, and W.N. Bruce. 1975. Thatch development and other effects and preemergence herbicides in Kentucky bluegrass turf. Agron. J. 67:563-565.

Woolson, E. A., J.H. Axley, and P.C. Kearney. 1973. The chemistry and phytotoxicity of arsenic in soils: H. Effects of time and phosphorus. Soil Sci. Soc. Amer. Proc. 37:254-259. 